\title{
Inadequate Empirical Antibiotic Therapy in Hospital Acquired Pneumonia
}

\author{
Santosh Dahal, ${ }^{1}$ Basista Prasad Rijal, ${ }^{1}$ Karbir Nath Yogi, ${ }^{2}$ Jeevan Bahadur Sherchand, ${ }^{1}$ Keshab Parajuli, \\ Narayan Parajuli,' Bharat Mani Pokhrel' \\ 'Department of Microbiology, Institute of Medicine, Tribhuvan University, Kathmandu, Nepal, ${ }^{2}$ Department of Respiratory \\ Medicine, Institute of Medicine, Tribhuvan University, Kathmandu, Nepal.
}

\section{ABSTRACT}

Introduction: Inadequate empirical antibiotic therapy for HAP is a common phenomena and one of the indicators of the poor stewardship. This study intended to analyze the efficacy of empirical antibiotics in the light of microbiological data in HAP cases.

Methods: Suspected cases of HAP were followed for clinico-bacterial evidence, antimicrobial resistance and pre and post culture antibiotic use. The study was taken from February,2014 to July 2014 in department of Microbiology and department of Respiratory medicine prospectively. Data was analyzed by Microsoft Office Excel 2007.

Results: Out of 758 cases investigated, 77(10\%) cases were HAP, 65(84\%) of them were culture positive and $48(74 \%)$ were late in onset. In early onset cases, isolates were Acinetobacter $10(42 \%)$, Escherichia coli 5(21\%), S.aureus 4(17\%), Klebsiella 1(4\%) and Pseudomonas 1(4\%). From the late onset cases Acinetobacter 15(28\%), Klebsiella 17(32\%) and Pseudomonas 13(24\%) were isolated. All Acinetobacter, 78\% Klebsiella and 36\% Pseudomonas isolates were multi drug resistant. Empirical therapies were inadequate in 12(70\%) of early onset cases and 44(92\%) of late onset type. Cephalosporins were used in 7(41\%) of early onset infections but found to be adequate only in 2(12\%) cases. Polymyxins were avoided empirically but after cultures were used in 9(19\%) cases.

Conclusions: Empirical antibiotics were vastly inadequate, more frequently so in late onset infections. Use of cephalosporins empirically in early onset infections and avoiding empirical use of polymyxin antibiotics in late onset infections contributed largely to the findings. Inadequate empirical regimen is a real time feedback for a practitioner to update his knowledge on the local microbiological trends.

Keywords: empirical therapy; hospital acquired pneumonia.

\section{INTRODUCTION}

Hospital acquired pneumonia (HAP) is defined as pneumonia that develops after 48 hours of hospital admission in a non-incubating patient. ${ }^{1}$ It includes ventilator associated pneumonia (VAP) and pneumonia in non ventilated patients. HAP is termed as 'earlyonset' if infection occurs within the first 96 hours of admission and 'late-onset' if infection arises later. ${ }^{2}$ Effective empirical therapies have been shown to decrease the overall morbidity and mortality associated with HAP. ${ }^{3,4}$
Inadequate empirical antibiotic therapy (IEAT) is a common problem and the efficacy of empirical regimen becomes a research area frequently. ${ }^{3}$ Empirical therapy can only be efficient when they correlate well with microbiological data and are timely evaluated and updated.

Correspondence: Dr. Santosh Dahal, Department of Microbiology, Institute of Medicine, Tribhuvan University, Kathmandu, Nepal. Email: sandahal.np@gmail.com, Phone: +977-9851152752. 
The objective of this study was to determine the bacterial etiology of HAP cases, resistance patterns among the clinical isolates and to analyze antibiotic use before and after the culture results.

\section{METHODS}

It was a prospective observational study undertaken for a six months period through February to July 2014 in department of Microbiology and department of Respiratory medicine. Ethical approval was taken from the institutional review board and informed consent was taken with the patients before enrolling them into the study. Probable HAP cases were defined as per Centers for Disease Control and Prevention (CDC)/NHSN (National Healthcare Safety Network) guidelines. ${ }^{5}$ Repeated cases of HAP were excluded. Semi-quantitative cultures were performed on bronchoalveolar lavage (BAL) and endotracheal aspirate (ETA) but sputum cultures were qualitative. Antibiotic sensitivity was performed on all isolates by disc diffusion method. Isolates resistant to any antibiotic in 3 or more groups were defined as multi drug resistant (MDR). ${ }^{6}$ Extended spectrum beta lactamase (ESBL), and metallobeta lactamase (MBL) production was determined by combined disc method as described by CLSI. ${ }^{7}$ Patients were followed up and the patterns of antibiotic use before and after the culture results were noted. Data was analyzed by Microsoft Office Excel 2007.

\section{RESULTS}

Out of 758 cases investigated, $77(10 \%)$ cases were defined to be HAP and among them 65 (84\%) were culture positive. Out of the bacterial isolates 72 (93\%) were gram negatives and majority of them were nonfermenters. Acinetobacter, Klebsiella and Pseudomonas were the most common isolates. (Table 1)

\begin{tabular}{|c|c|c|}
\hline Organism & $\begin{array}{c}\text { Early (\%) } \\
(n=14)\end{array}$ & $\begin{array}{c}\text { Late }(\%) \\
(n=46)\end{array}$ \\
\hline $\begin{array}{l}\text { Acinetobacter } \\
\text { calcoaceticus } \\
\text { baumanii Complex }\end{array}$ & $8(34.8)$ & $15(65.2)$ \\
\hline Klebsiella pneumoniae & $1(5.6)$ & $17(94.4)$ \\
\hline $\begin{array}{l}\text { Pseudomoans } \\
\text { aeruginosa }\end{array}$ & $1(7.1)$ & $13(92.9)$ \\
\hline Escherichia coli & 5 & 3 \\
\hline Staphylococcus aureus & $4(80.0)$ & $1(20.0)$ \\
\hline
\end{tabular}

Majority $48(74 \%)$ of the infections were late in onset. Empirical therapies were adequate in $30 \%$ of early onset infections, and $8 \%$ of late onset infections. (Table 2)

\begin{tabular}{|llll|}
\hline \multicolumn{4}{|c|}{ Table 2. Adequacy of empirical therapy. } \\
\hline & $\begin{array}{l}\text { Early HAP } \\
(\%)\end{array}$ & $\begin{array}{l}\text { Late HAP } \\
(\%)\end{array}$ & Total $(\%)$ \\
Adequate & $5(29.4 \%)$ & $4(8.34 \%)$ & $9(13.8 \%)$ \\
Inadequate & $12(70.6 \%)$ & $\begin{array}{l}4 \\
(91.67 \%)\end{array}$ & $\begin{array}{l}56 \\
(86.2 \%)\end{array}$ \\
Total & $17(100 \%)$ & $48(100 \%)$ & $65(100 \%)$ \\
\hline
\end{tabular}

Acinetobacter (100\%), Klebsiella (77.8\%) and Pseudomonas $(36 \%)$ were multi drug resistant. Out of 65 isolates $20(32 \%)$ isolates were found to be ESBL producers and 24 (38\%) were found to be MBL producers. ESBL production was most common in Klebsiella spp. (55\%) and MBL production was most common in Acinetobacter spp (74\%).

In early onset HAP (Table 3) third generation cephalosporins were used in $7(41 \%)$ of early onset infections but found to be adequate only in $2(12 \%)$ of cases. Polymyxins were avoided empirically but after cultures were used in $9(19 \%)$ cases all of which were late in onset. (Table 4)

\begin{tabular}{|c|c|c|c|}
\hline Empirical therapy & $\begin{array}{l}\text { No of } \\
\text { cases }\end{array}$ & $\begin{array}{l}\text { Adjusted } \\
\text { therapy }\end{array}$ & $\begin{array}{l}\text { No of } \\
\text { cases }\end{array}$ \\
\hline Cephalosporin & 7 & $\begin{array}{l}\text { Piperacillin } \\
\text { tazobactum }\end{array}$ & 8 \\
\hline Levofloxacin & 5 & Levofloxacin & 6 \\
\hline $\begin{array}{l}\text { Piperacillin } \\
\text { tazobactum }\end{array}$ & 5 & $\begin{array}{l}\text { Meropenem/ } \\
\text { Imipenem }\end{array}$ & 5 \\
\hline $\begin{array}{l}\text { Meropenem/ } \\
\text { Imipenem }\end{array}$ & 4 & $\begin{array}{l}\text { Amikacin/ } \\
\text { Zentamicin }\end{array}$ & 4 \\
\hline $\begin{array}{l}\text { Amikacin/ } \\
\text { Zentamicin }\end{array}$ & 4 & Cephalospoins & 2 \\
\hline $\begin{array}{l}\text { Amoxycillin } \\
\text { clavulanate }\end{array}$ & 3 & $\begin{array}{l}\text { Amoxycillin } \\
\text { clavulanate }\end{array}$ & 1 \\
\hline
\end{tabular}

\section{DISCUSSIONS}

The objective of this study was to analyze antibiotic use in HAP cases against the culture results, bacterial etiology and their resistance patterns. Empirical antibiotic were found to be inadequate and upgraded in 
$70 \%$ of early onset HAP and $92 \%$ of late onset HAP as per the culture results. Various studies have reported different rates of inadequacies in empirical treatment ranging from $41 \%$ to 66 percent. ${ }^{8-11}$ The rates in the present study are higher than those reported.

\begin{tabular}{|c|c|c|c|}
\hline Empirical therapy & $\begin{array}{l}\text { No of } \\
\text { cases }\end{array}$ & Adjusted therapy & $\begin{array}{l}\text { No of } \\
\text { cases }\end{array}$ \\
\hline $\begin{array}{l}\text { Meropenem/ } \\
\text { Imipenem }\end{array}$ & 10 & $\begin{array}{l}\text { Polymyxin B/ } \\
\text { Colistin }\end{array}$ & 9 \\
\hline Levofloxacin & 7 & $\begin{array}{l}\text { Piperacillin } \\
\text { tazobactum }\end{array}$ & 8 \\
\hline $\begin{array}{l}\text { Piperacillin } \\
\text { tazobactum }\end{array}$ & 6 & $\begin{array}{l}\text { Amikacin/ } \\
\text { Zentamicin }\end{array}$ & 7 \\
\hline $\begin{array}{l}\text { Amikacin/ } \\
\text { Zentamicin }\end{array}$ & 5 & Levofloxacin & 6 \\
\hline Ceftriaxone & 2 & $\begin{array}{l}\text { Imipenem/ } \\
\text { Meropenem }\end{array}$ & 6 \\
\hline $\begin{array}{l}\text { Ciprofloxacin/ } \\
\text { Ofloxacin }\end{array}$ & 2 & Tigecycline & 4 \\
\hline
\end{tabular}

Various factors can be held accountable for the failure of empirical regimen. A high majority $(77 \%)$ of the bacterial isolates in the study were MDR, one of the prime factors resulting in IEAT. It is recommended that risk factors for MDR in each patient should be assessed individually before prescribing antibiotics. ${ }^{12}$ Major risk factors being prior antimicrobial therapy, late onset infection, high frequency of antibiotic resistance in the hospital and community, family members with known MDR pathogen, and immunosuppressive therapy. ${ }^{2}$ In agreement with the above, this study showed IAET to be more common in late onset cases. A study has reported that the risk of inadequate antimicrobial treatment is two-fold in late-onset VAP cases and three-fold more in VAP by MDR pathogen. ${ }^{8}$ Piskin also showed that 80 $\%$ and $87 \%$ of HAP and VAP cases respectively with inadequate initial antibiotic therapy were late in onset. ${ }^{9}$ Another study found that prevalence of Acinetobacter spp. was one of the determining factors for empirical antibiotic choice. ${ }^{13}$ Acinetobacter is the most common isolate in the study comprising $32 \%$ of all isolates. Despite all the facts, efficacy of empirical antibiotics can be improved if they are targeted against the prevalent bacterial isolates and their resistance pattern.

In this study, early onset infections were treated most commonly with third generation cephalosporins usually in the non intensive settings initially only to be replaced after culture results indicating the fact that the practice was incoherent with the institutional microbiological data. Etiology of early onset infections in the study comprised of notorious nosocomial pathogens. (Table 1) The reports on etiology of early onset HAP are varied $^{14-18}$ and thus the empirical choices need to be tailored to the current prevalent etiological pattern in the practice setup. Study also found that polymyxins were completely avoided in empirical therapy but were used after they were the only sensitive antibiotic group reported. Completely avoiding polymyxins empirically indicated failure in addressing the prevalence of Acinetobacter infections with polymyxins as the only choice of treatment. Hesitation in use of polymyxins is understood on the grounds of its widely perceived toxicities and debated efficacy but analysis of published clinical evidence reinforces that colistin is indeed an effective and acceptably safe choice in the treatment of VAP in the era of "bad bugs-no drugs. ${ }^{19}$ And when required they can been be used empirically. ${ }^{12,13}$ Interestingly, Acinetobacter infections were common isolates in both early and late onset infections but the isolates from late onset were the ones with polymyxins as the only sensitive group. Apparently there can be no prescribed antibiotic regimen to ensure the adequacy of treatment in HAP, the best regimen is the one based on local pathogen susceptibility patterns. ${ }^{3}$

This study simply analyzes the antibiotic use before and after cultures without questioning the appropriateness of such practices and the cases enrolled were probable HAP cases. Practice in ventilated patients (VAP) and in non ventilated patients has not been analyzed separately; also the efficacy of individual empirical antibiotic regimen was not studied.

The study reflects the crisis situation in resource starved large hospital settings in developing countries without significant antibiotic stewardship strategies and the threat posed by increasingly drug resistant Acinetobacter infection. While it is of paramount importance to avoid unnecessary use of antibiotics, inadequacy in empirical therapy can be deleterious in drug resistant infections such as HAP. A message for the clinical practitioners in similar settings is, in case your antibiotics prescription needs to be upgraded frequently after culture reports, it is the real time feedback for you and you might want to revisit the local microbiology laboratory.

\section{CONCLUSIONS}

The study reflects the crisis situation in resource starved large hospital settings in developing countries without significant antibiotic stewardship strategies and the threat posed by increasingly drug resistant Acinetobacter infection. While it is of paramount importance to avoid unnecessary use of antibiotics, inadequacy in empirical therapy can be deleterious in drug resistant infections such as HAP. In case the antibiotics prescription needs to be upgraded frequently after culture reports, it is the real time feedback for the practitioner that the regimen 
needs to be revised and it might be the time to revisit the local microbiology laboratory.

\section{ACKNOWLEDGEMENT}

We thank all the participants in the study, Mr. Hari kattel, Dr. Andrew Trotter and staff of microbiology lab for their help during the period of study.

\section{REFERENCES}

1. Tablan OC, Anderson LJ, Arden NH, Breiman RF, Butler JC, McNeil MM. Guideline for prevention of nosocomial pneumonia. The Hospital Infection Control Practices Advisory Committee, Centers for Disease Control and Prevention. Infect Control Hosp Epidemiol. 1994;15(9):587-627.

2. American Thoracic Society. Guidelines for the management of adults with hospital-acquired, ventilator-associated, and healthcare-associated pneumonia. Am J Respir Crit Care Med. 2005;171(4):388-416.

3. Swanson JM, Wells DL. Empirical Antibiotic Therapy for Ventilator-Associated Pneumonia. Antibiotics [Internet]. 201317 June 2015; 2:[339-51 pp.].

4. Borer A, Saidel-Odes L, Riesenberg K, et al. Attributable mortality rate for carbapenem-resistant Klebsiella pneumoniaebacteremia. Infect Control Hosp Epidemiol 2009;30:972-6.

5. CDC/NHSN Surveillance Definitions for Specific Types of Infections. Centers for Disease Control and Prevention 2014.

6. Magiorakos AP, Srinivasan A, Carey RB, Carmeli $Y$, Falagas ME, Giske CG, et al. Multidrug-resistant, extensively drug-resistant and pandrug-resistant bacteria: an international expert proposal for interim standard definitions for acquired resistance. Clin Microbiol Infect. 2012;18(3):268-81.

7. CLSI. Clinical laboratory Standard institute, performance guidelines for antimicrobial susceptibility testing, twenty second informational supplement. 2012(M100).

8. Teixeira PJ, Seligman R, Hertz FT, Cruz DB, Fachel JM. Inadequate treatment of ventilator-associated pneumonia: risk factors and impact on outcomes. J Hosp Infect. 2007;65(4):361-7.

9. Piskin N, Aydemir H, Oztoprak N, Akduman D, Comert $\mathrm{F}$, Kokturk $\mathrm{F}$, et al. Inadequate treatment of ventilatorassociated and hospital-acquired pneumonia: risk factors and impact on outcomes. BMC Infect Dis. 2012;12(268):1471-2334.

10. Alvarez-Lerma F. Modification of empiric antibiotic treatment in patients with pneumonia acquired in the intensive care unit. ICU-Acquired Pneumonia Study Group. Intensive Care Med. 1996;22(5):387-94.
11. Werarak P, Kiratisin P, Thamlikitkul V. Hospital-acquired pneumonia and ventilator-associated pneumonia in adults at Siriraj Hospital: etiology, clinical outcomes, and impact of antimicrobial resistance. J Med Assoc Thai. 2010;93(1):S126-38.

12. Gupta D, Agarwal R, Aggarwal AN, Singh N, Mishra N, Khilnani GC, et al. Guidelines for diagnosis and management of community- and hospital-acquired pneumonia in adults: Joint ICS/NCCP(I) recommendations. Lung India. 2012;29(Suppl 2):S27-62.

13. Rello J, Ulldemolins M, Lisboa T, Koulenti D, Manez R, Martin-Loeches I, et al. Determinants of prescription and choice of empirical therapy for hospital-acquired and ventilator-associated pneumonia. Eur Respir J. 2011;37(6):1332-9.

14. Quartin AA, Scerpella EG, Puttagunta S, Kett DH. A comparison of microbiology and demographics among patients with healthcare-associated, hospital-acquired, and ventilator-associated pneumonia: a retrospective analysis of 1184 patients from a large, international study. BMC Infect Dis. 2013;13(561):1471-2334.

15. Joseph NM, Sistla S, Dutta TK, Badhe AS, Rasitha D, Parija SC. Ventilator-associated pneumonia in a tertiary care hospital in India: role of multi-drug resistant pathogens. J Infect Dev Ctries. 2010;4(4):218-25.

16. Merchant $\mathrm{M}$, Karnad DR, Kanbur AA. Incidence of nosocomial pneumonia in a medical intensive care unit and general medical ward patients in a public hospital in Bombay, India. J Hosp Infect. 1998;39(2):143-8.

17. ReechaipichitkulW, PhondongnokS, BourpoernJ, Chaimanee $P$. Causative agents and resistance among hospital-acquired and ventilator-associated pneumonia patients at Srinagarind Hospital, northeastern Thailand. Southeast Asian J Trop Med Public Health. 2013;44(3):490-502.

18. Zhao T, Liu Y, Cao B, Wang H, Chen L, She D, et al. Prospective multicenter study of pathogen distributions in early-onset and late-onset hospital-acquired pneumonia in china. Antimicrob Agents Chemother. 2013;57(12):6404-5.

19. Falagas ME, Rafailidis PI. Colistin in Ventilator-Associated Pneumonia. Clinical Infectious diseases. 2012;54(5):681-3. 